\title{
Review
}

Respiration 2017;94:299-311

Received: December 16, 2016

DOI: $10.1159 / 000479089$

Accepted after revision: June 28, 2017

Published online: July 25, 2017

\section{Risk Factors for Community-Acquired Pneumonia in Adults: A Systematic Review of Observational Studies}

\author{
Jordi Almirall ${ }^{a} b$ Mateu Serra-Prat ${ }^{c, d}$ Ignasi Bolíbar ${ }^{\mathrm{e}}{ }^{\mathrm{f}}$ Valentina Balasso $^{g}$ \\ antensive Care Unit, Hospital de Mataró, Autonomous University of Barcelona, Consorci Sanitari del Maresme, \\ Mataró, ${ }^{b}$ Centro de Investigación Biomédica en Red de Enfermedades Respiratorias (CIBERES), Madrid, ${ }^{\mathrm{C}}$ Research \\ Unit, Consorci Sanitari del Maresme, Mataró, ${ }^{d}$ Centro de Investigación Biomédica en Red de Enfermedades \\ Hepáticas y Digestivas (CIBEREHD), Madrid, ${ }^{e}$ Clinical Epidemiology and Public Health, Institut of Biomedical \\ Research (IIB Sant Pau), Hospital de la Santa Creu i Sant Pau, Autonomous University of Barcelona, Barcelona, \\ ${ }^{f}$ Consorcio de Investigación Biomédica en Red de Epidemiología y Salud Pública (CIBERESP), Madrid, and \\ glberoamerican Cochrane Center, Clinical Epidemiology and Public Health, Institut of Biomedical Research (IIB Sant \\ Pau), Hospital de la Santa Creu i Sant Pau, Barcelona, Spain
}

\section{Keywords}

Community-acquired pneumonia - Risk factors · Adults · Systematic review - Observational studies

\begin{abstract}
We performed a systematic review of the literature to establish conclusive evidence of risk factors for community-acquired pneumonia (CAP). Observational studies (cross-sectional, case-control, and cohort studies) the primary outcome of which was to assess risk factors for CAP in both hospitalized and ambulatory adult patients with radiologically confirmed pneumonia were selected. The NewcastleOttawa Scale specific for cohort and case-control designs was used for quality assessment. Twenty-nine studies (20 case-control, 8 cohort, and 1 cross-sectional) were selected, with $44.8 \%$ of them focused on elderly subjects $\geq 65$ years of age and $34.5 \%$ on mixed populations (participants' age $>14$ years). The median quality score was 7.44 (range 5-9). Age, smoking, environmental exposures, malnutrition, previous CAP, chronic bronchitis/chronic obstructive pulmonary disease, asthma, functional impairment, poor dental health, im-
\end{abstract}

\section{KARGER}

(C) 2017 S. Karger AG, Basel

E-Mail karger@karger.com

www.karger.com/res munosuppressive therapy, oral steroids, and treatment with gastric acid-suppressive drugs were definitive risk factors for CAP. Some of these factors are modifiable. Regarding other factors (e.g., gender, overweight, alcohol use, recent respiratory tract infections, pneumococcal and influenza vaccination, inhalation therapy, swallowing disorders, renal and liver dysfunction, diabetes, and cancer) no definitive conclusion could be established. Prompt assessment and correction of modifiable risk factors could reduce morbidity and mortality among adult CAP patients, particularly among the elderly.

(c) 2017 S. Karger AG, Basel

\section{Introduction}

Community-acquired pneumonia (CAP) remains an important cause of morbidity and mortality in industrialized countries. In the general adult population, the annual incidence of CAP ranges between 1.6 and 13.4 cases per 1,000 inhabitants, $22-51 \%$ of whom require inpatient care, with a lethality of $3-24 \%$. The mortality rate varies

Jordi Almirall, $\mathrm{MD}, \mathrm{PhD}$

Intensive Care Unit, Hospital de Mataró

Carretera de la Cirera s/n

ES-08304 Mataró, Barcelona (Spain)

E-Mail jalmirall@ csdm.cat 
between 0.1 and 0.7 per 1,000 persons each year [1]. Despite considerable research, great improvement in medical care, and advances in antimicrobial therapy with the availability of active antibiotics against the known causative pathogens, mortality from CAP has not improved during the last decades. Targeted risk reduction interventions based on understanding and recognizing risk factors for CAP are of primary importance in reducing CAPrelated death rates [2].

So far, only 1 systematic review analyzing risk factors for CAP has been published in the literature [3]. This study, however, was published in German and the search was limited to the MEDLINE database, including articles published between 1996 and December 2003. In the last years, new data have been published, sometimes corroborating previous evidence, sometimes with controversial results and in other occasions suggesting new possible risk factors that need to be further studied. These studies have different designs, methodological quality, and populations, have measured different risk factors, or have assessed the same risk factors in different ways. Therefore, they not always report conclusive and concordant results.

Because of this heterogeneity, there is a need to update all the evidence to reach a more definitive conclusion for the studied factors. Our systematic review not only updates the earlier review of Kohlhammer et al. [3] published in 2005, but also summarizes the scientific evidence from observational studies about risk factors for CAP in adults.

\section{Methods}

\section{Study Selection}

Observational studies in which the primary outcome was to assess risk factors for CAP in both hospitalized and ambulatory adult patients with radiologically confirmed pneumonia were selected for the study. Observational studies included cross-sectional, casecontrol, and cohort study designs. Exclusion criteria were as follows: (a) studies addressing other aspects of CAP, such as bacteremia, health care-acquired pneumonia, hospital-acquired pneumonia, and CAP caused by antibiotic-resistant pathogens; (b) studies focused on prognostic or treatment-related factors for CAP; and (c) studies of CAP carried out in specific populations, such as patients with diabetes mellitus, chronic obstructive pulmonary disease (COPD), or HIV infection.

The search was conducted according to the Preferred Reporting Items for Systematic Reviews and Meta-Analyses (PRISMA) [4]. The electronic databases PubMed MEDLINE (US National Library of Medicine, Bethesda, MD, USA) and EMBASE Elsevier were systematically searched until June 30,2015 . The search strategy is detailed in online supplementary Table 1 (for all online suppl. material, see www.karger.com/doi/10.1159/000479089). Reports published in English, Spanish, and French were consid- ered. Potentially relevant articles were screened for eligibility independently in an unblinded standardized manner by the two reviewers (J.A. and V.B.), initially by abstract and then by full text if necessary, to determine whether they met the inclusion criteria. Disagreement between the reviewers was resolved by discussion with the rest of the researchers. The reference lists of the identified articles were manually searched for additional studies that may have been overlooked using the computer-assisted search strategy.

\section{Data Extraction}

We developed a data extraction sheet, pilot-tested it on 3 randomly selected included studies, and refined it accordingly. One author (J.A.) extracted the data from the included studies and a second author (M.S.-P.) checked the extracted data. Disagreements were resolved by discussion between the two review authors. The following information was extracted from each included paper: authors and year of publication; study design; characteristics of study participants (number, mean age, and gender); and risk factors for CAP. In order to reinforce the confidence of the predictive effect of risk factors for CAP, only those factors that were individually analyzed in at least 3 studies were considered. The number of at least 3 studies was arbitrarily decided on, because of the possibility of disagreement between only 2 studies. Risk factors were grouped into the broad categories of sociodemographic and lifestyle factors, comorbidities or clinical conditions, and therapeutic factors.

\section{Quality Assessment}

The quality of all included studies was evaluated using the Newcastle-Ottawa Scale (NOS) for nonrandomized studies. The NOS specific for cohort and case-control designs was used [5], with an overall quality score ranging from 0 (minimum) to 9 (maximum) stars. Discrepancies in quality assessment were discussed and resolved by three authors (J.A., I.B, and V.B.).

\section{Data Synthesis and Analysis}

The quality and concordance of the evidence was used to develop standardized statements for each risk factor. For each analysis in each individual study, the resulting effect of the risk factors was categorized as "significant risk factor," "significant protective factor," or "nonsignificant risk factor." Only the results of multivariate adjusted models were taken into account. If a given category (significant risk factor, significant protective factor, or nonsignificant risk factor) was present in $>66 \%$ of the studies and the other categories in $\leq 34 \%$ of the studies, and the given category had no clearly lower methodological quality, then standardized statements of "clear risk factor," "clear protective factor," or "no effect" were established; otherwise, a statement of "no definitive conclusion" was considered (Table 1). No clearly lower methodological quality was considered if the difference in median NOS scores between categories was $<1$ point.

Whenever a factor was analyzed more than once in a study (e.g., it was included in $\geq 2$ predictive models for CAP), it was counted in all the categories that applied. In these cases, the percentages of the "risk/protection/no effect" categories added up to $>100 \%$, and the standardized statement was extended as follows: if two categories had $>66 \%$ of the studies and one category had a higher methodological quality than the other, then the statement was "possible risk factor/possible protective factor/possible no effect." Each factor was classified according to its predictive profile (risk factor, 
Table 1. Standardized definitions of the confidence of the predictive effect of risk factors for CAP

\begin{tabular}{llll}
\hline $\begin{array}{l}\text { Categories of effect } \\
\text { of risk factors }\end{array}$ & $\begin{array}{l}\text { Percentage of studies } \\
\text { favoring the effect }\end{array}$ & $\begin{array}{l}\text { NOS quality versus other } \\
\text { categories of effect }\end{array}$ & Standardized definition \\
\hline Significant risk factor & $>66 \%$ & $\begin{array}{l}\text { Higher } \\
\text { Lower }\end{array}$ & $\begin{array}{l}\text { Clear risk factor } \\
\text { No definitive conclusion }\end{array}$ \\
\hline Significant protective factor & $>66 \%$ & $\begin{array}{l}\text { Higher } \\
\text { Lower }\end{array}$ & $\begin{array}{l}\text { Clear protective factor } \\
\text { No definitive conclusion }\end{array}$ \\
\hline $\begin{array}{l}\text { Nonsignificant risk factor } \\
\text { Significant risk factor }\end{array}$ & $>66 \%$ & $\begin{array}{l}\text { Higher } \\
\text { Lower }\end{array}$ & No effect \\
$\begin{array}{l}\text { Significant protective factor } \\
\text { Nonsignificant risk factor }\end{array}$ & $\leq 66 \%$ & $\begin{array}{l}\text { Not applicable } \\
\text { Not applicable }\end{array}$ & No definitive conclusion \\
\hline
\end{tabular}

CAP, community-acquired pneumonia; NOS, Newcastle-Ottawa Scale.

protective factor, or no effect) and to the standardized consideration of the confidence that could be placed on that profile (clear, possible, or no definitive conclusion). To analyze and synthesize the evidence, for each risk factor we present the number of publications and the number of analyses in the three possible categories of effect, specifying the number of publications on elderly patients. We also present the median score (range) on the NOS, and, for those that are clearly risk or protective factors, the estimated effect independent from the multivariate models. It is expressed as the median (range) of all the adjusted odds ratios (OR), from the categories of clear risk/protective, and from those publications that presented risk factors in a homogeneous way to allow its synthesis (i.e., similar cutoff points or categorization and similar measure of the risk factor).

\section{Results}

\section{Search Results}

The electronic search strategy identified a total of 2,731 records from electronic databases, 114 of which were retrieved for full paper evaluation. Of these 114 full papers, 36 met the eligibility criteria and were subjected to data extraction $[2,6,7-40]$. However, these 36 articles referred to only 29 studies, since in 5 cases the same study or different aspects of the same study were published in more than 1 article $[2,7,8,10-12,24,25,32,33,39,40]$. Therefore, a total of 29 studies were included for qualitative synthesis (Fig. 1).

\section{Characteristics of the Studies}

Twenty studies (70\%) had a case-control design, 8 (27.6\%) had a cohort design, and 1 (3.4\%) had a cross- sectional design (Table 2). The case-control and crosssectional studies included 29,018 participants. The cohort studies were prospective in 6 cases and retrospective in 2 , and overall they included more than 140,000 participants. The cohort studies were published between 1994 and 2015, with the longest follow-up being 16 years and 11 months. Most studies focused on elderly subjects $\geq 65$ years of age (44.8\%) or mixed populations where the participants' age was $>14$ years (34.5\%), and a few studies $(13.8 \%)$ considered only the age range between 18 and 60 years. The definitions used for cases and controls, as well as exposed and nonexposed subjects, in each of the included studies are detailed in online supplementary Table 2 .

\section{Quality Assessment}

The median quality score of the studies was 7.44 (range 5-9). The median quality score of the case-control and cross-sectional studies was 7.42 , which was very similar to that of the cohort studies (7.5).

\section{Evidence Synthesis}

Sociodemographic and Lifestyle Factors

Clear risk factors for CAP were age, smoking, poor nutritional status, and environmental exposures to different substances (metals, dust, fumes, etc.) (Table 3). No definitive conclusions were drawn for the effect of male gender and alcohol use. No effect was demonstrated for overweight and passive smoking in the overall adult population.

Risk Factors for Community-Acquired

Pneumonia in Adults 


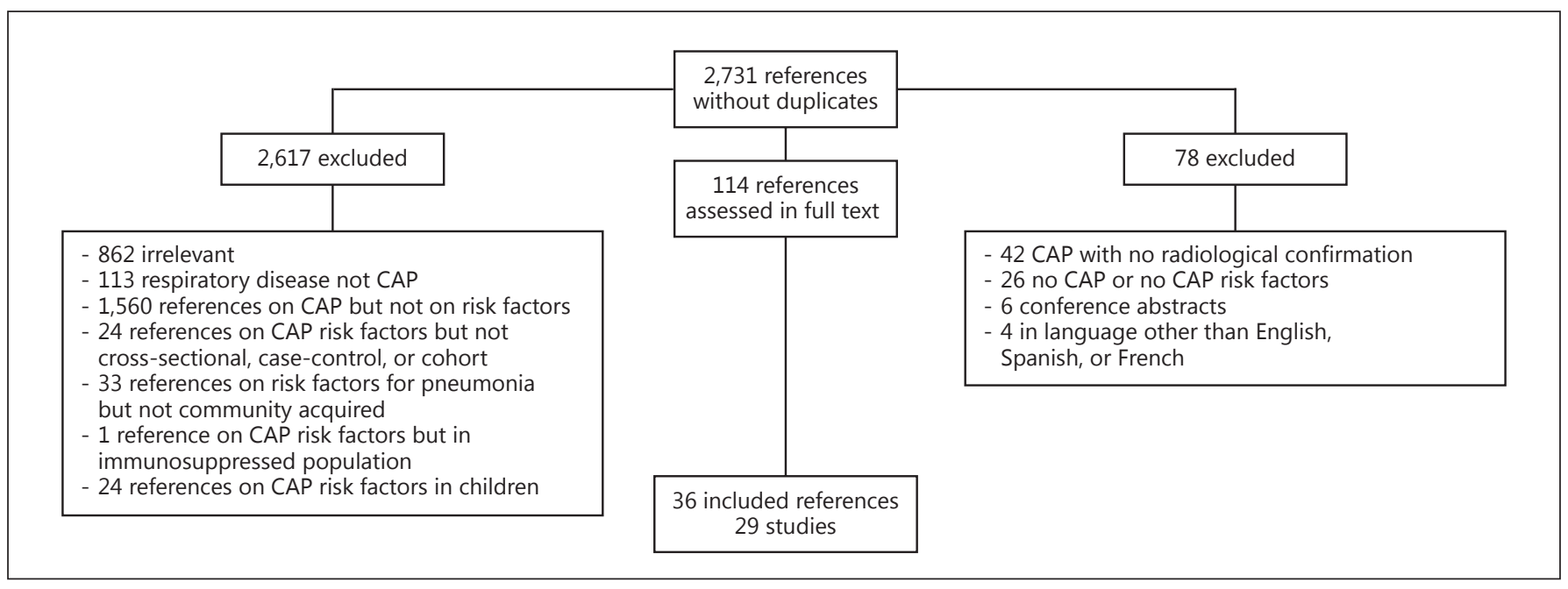

Fig. 1. Flowchart of the studies included in this review. CAP, community-acquired pneumonia.

Comorbidities or Clinical Conditions

As shown in Table 4, functional impairment, COPD/ chronic bronchitis, asthma, a history of CAP, and orodental and/or periodontal diseases were clear risk factors for CAP. Recent upper respiratory tract infections showed to be a possible risk factor. Chronic heart disease, dysphagia, cancer, chronic liver disease, and diabetes allowed no definitive conclusion, while chronic renal disease showed no effect.

Therapeutic Factors

Immunosuppressive treatment, use of oral steroids, and proton pump inhibitors or $\mathrm{H}_{2}$ blockers were classified as clear risk factors for CAP (Table 5). Treatment with antibiotics for any reason prior to admission for CAP and influenza vaccines had no effect, whereas the role of inhaled drugs remained in the "no definitive conclusion" category. Pneumococcal vaccination (polysaccharide 23V) was classified in the "possibly no effect" category.

The results of other, less studied factors (i.e., individually analyzed in $<3$ studies) are detailed in Table 6.

\section{Discussion}

This study shows conclusive evidence of age, smoking habit, environmental exposures, poor nutritional status, functional impairment, chronic bronchitis/COPD, asthma, previous CAP (in the past 1 or 2 years), poor oral health, immunosuppressive therapy, oral steroids, and treatment with proton pump inhibitors or $\mathrm{H}_{2}$ antagonists as risk factors for CAP in adults. No effect was found for other factors, including overweight, passive smoking, influenza vaccine, use of antibiotics before CAP, and chronic renal disease. Also, the role of male gender, alcohol use, passive smoking in the older age subgroup, heart disease, dysphagia, cancer, chronic liver disease, diabetes, use of inhalers, and pneumococcal vaccine remained inconclusive. A large number of other potential risk factors for CAP (detailed in Table 6) need to be further studied.

Age is a well-known risk factor for CAP, especially in older people. In 2 studies carried out on subjects of all ages, significant results were only found for the oldest segment of the population $[14,20]$, whereas in 1 study on young people [14], age was not a significant factor. These findings may suggest a nonlinear effect, with older age as a risk factor for CAP. Age may also modify or interact with other factors in elderly people. Active smoking has a direct and independent effect on the risk of pneumonia, but it may also act indirectly, causing COPD, which is a well-recognized risk factor for CAP. In relation to gender, the results of the studies are conflicting. In our systematic review, male gender was a significant risk factor in 4 analyses and a nonsignificant factor in 3 studies. Women are often less represented than men in COPD populations, and typically smoke substantially less than men. Only 3 studies $[2,21,30]$ assessed the effect of passive smoking, 2 of which showed no significant effect $[2,21]$. However, the third study [30], of somewhat greater quality, observed a significant effect in elderly subjects, in whom the lung defense mechanisms might be insufficient 
Table 2. General characteristics of the 29 studies included in the systematic review of risk factors for CAP

\begin{tabular}{|c|c|c|c|c|c|}
\hline $\begin{array}{l}\text { First author, } \\
\text { country }\end{array}$ & $\begin{array}{l}\text { Year } \\
\text { [Ref.] }\end{array}$ & Design & Number of participants & Age and representativeness & $\begin{array}{l}\text { NOS } \\
\text { quality } \\
\text { score }\end{array}$ \\
\hline Almirall, Spain & $1999[6]$ & Case-control & Cases, $n=205$; controls, $n=475$ & $\begin{array}{l}>14 \text { years; outpatients and hospitalized } \\
\text { pneumonia cases, population controls }\end{array}$ & 7 \\
\hline \multirow[t]{2}{*}{ Almirall, Spain } & $\begin{array}{l}2008[2] \\
2015[7]\end{array}$ & \multirow[t]{2}{*}{ Case-control } & Cases, $n=1,336$; controls, $n=1,326$ & \multirow[t]{2}{*}{$\begin{array}{l}\text { >14 years; outpatients and hospitalized } \\
\text { pneumonia cases, population controls }\end{array}$} & \multirow[t]{2}{*}{7} \\
\hline & $\overline{2010[8]}$ & & Cases, $n=437$; controls, $n=235$ & & \\
\hline Almirall, Spain & $2013[9]$ & Case-control & Cases, $n=36$; controls, $n=72$ & $\begin{array}{l}\geq 70 \text { years; hospitalized cases consecutively } \\
\text { included in the study, population controls }\end{array}$ & 9 \\
\hline $\begin{array}{l}\text { Alperovich, USA } \\
\text { Neuman, USA } \\
\text { Neuman, USA }\end{array}$ & $\begin{array}{l}2007[10] \\
2007[11] \\
2010[12]\end{array}$ & Cohort & $\begin{array}{l}\text { Nurses' Health Study (NHS) II; } \\
\text { cohort, } n=83,165 \text { women; } 925 \text { cases } \\
\text { observed for } 650,377 \text { person-years }\end{array}$ & $\begin{array}{l}\text { Women aged } 27-44 \text { years; outpatients and } \\
\text { hospitalized pneumonia cases (follow-up } \\
10 \text { years) }\end{array}$ & 6 \\
\hline Atsumi, Japan & $2009[13]$ & Cross-sectional & $\begin{array}{l}\text { Total, } n=4,666 \text { patients; with CAP, } \\
n=313 \text {; without CAP, } n=4,353\end{array}$ & $\begin{array}{l}\text { Adults; hospitalized from a department with a } \\
\text { respiratory unit, an infectious unit, and a } \\
\text { digestive unit }\end{array}$ & 7 \\
\hline Baik, UK & $2000[14]$ & $\begin{array}{l}\text { Nested } \\
\text { case-control }\end{array}$ & $\begin{array}{l}\text { HPFS cohort of } 26,429 \text { men (cases, } \\
n=290 \text { ) and NHS II cohort of } 83,165 \\
\text { women (cases, } n=305)\end{array}$ & $\begin{array}{l}\text { Health professionals ( } 40-75 \text { years) and nurses } \\
(27-44 \text { years); cases and controls from the } \\
\text { HPFS and NHS II cohorts }\end{array}$ & 6 \\
\hline Dang, Canada & $2014[15]$ & Cohort & $\begin{array}{l}\text { Cohort, } n=2,709 ; \text { cases, } n=245 \\
\text { controls, } n=2,464\end{array}$ & $\begin{array}{l}>17 \text { years; cases and controls, survivors of a } \\
\text { hospitalized CAP and free of pneumonia for } \\
\geq 3 \text { months }\end{array}$ & 9 \\
\hline $\begin{array}{l}\text { de Melo Neto, } \\
\text { Brazil }\end{array}$ & $2013[16]$ & Case-control & Cases, $n=70$; controls, $n=70$ & $\geq 18$ years; hospitalized cases and controls & 8 \\
\hline Doshi, USA & $2011[17]$ & Case-control & Cases, $n=347$; controls, $n=694$ & Adults; hospitalized & 8 \\
\hline Eurich, Canada & $2010[18]$ & $\begin{array}{l}\text { Nested } \\
\text { case-control }\end{array}$ & $\begin{array}{l}\text { Cohort, } n=3,415 \text {; cases, } n=248 \\
\text { controls, } n=2,476\end{array}$ & $\begin{array}{l}\text { Population-based cohort of patients }>17 \text { years } \\
\text { of age admitted with CAP; cases were patients } \\
\text { aged } \geq 65 \text { years hospitalized for recurrent } \\
\text { pneumonia; matched controls were free of } \\
\text { pneumonia }\end{array}$ & 8 \\
\hline Eurich, Canada & $2013[19]$ & $\begin{array}{l}\text { Nested } \\
\text { case-control }\end{array}$ & $\begin{array}{l}\text { Cohort, } n=6,874 \text {; cases, } n=653 \text {; } \\
\text { controls, } n=6,244\end{array}$ & $\begin{array}{l}\text { Population-based cohort of patients }>17 \text { years } \\
\text { of age admitted with CAP; cases were patients } \\
\text { aged } \geq 65 \text { years hospitalized for recurrent } \\
\text { pneumonia; matched controls free of } \\
\text { pneumonia }\end{array}$ & 9 \\
\hline Farr, UK & $2000[20]$ & Case-control & Cases, $n=66$; controls, $n=489$ & $\begin{array}{l}\text { 15-79 years; community-diagnosed } \\
\text { pneumonia, population controls }\end{array}$ & 6 \\
\hline Farr, UK & $2000[21]$ & Case-control & Cases, $n=178$; controls, $n=385$ & $\begin{array}{l}18-75 \text { years; hospitalized cases having } \\
\text { survived a previous primary pneumonia, } \\
\text { population controls }\end{array}$ & 6 \\
\hline $\begin{array}{l}\text { Fernández-Solá, } \\
\text { Spain }\end{array}$ & $1995[22]$ & Case-control & Cases, $n=50$; controls, $n=50$ & $18-60$ years; hospitalized cases and controls & 7 \\
\hline Gau, USA & $2010[23]$ & Case-control & Cases, $n=194$; controls, $n=952$ & $\geq 65$ years; hospitalized cases and controls & 7 \\
\hline Jackson, USA & $\begin{array}{l}2003[24] \\
2004[25]\end{array}$ & $\begin{array}{l}\text { Retrospective } \\
\text { cohort ( } 3 \text { years) }\end{array}$ & $\begin{array}{l}\text { Cohort of } 47,365 \text { persons; } 3,061 \text { cases } \\
\text { observed for } 127,180 \text { person-years }\end{array}$ & $\begin{array}{l}\geq 65 \text {-year-old members of a health } \\
\text { maintenance organization; outpatient } \\
\text { pneumonia cases }\end{array}$ & 8 \\
\hline Jovanovich, USA & $2014[26]$ & $\begin{array}{l}\text { Retrospective } \\
\text { cohort } \\
\text { (3-15 months) }\end{array}$ & Cases, $n=66$; controls, $n=66$ & $\begin{array}{l}\text { Community-living adult individuals } \\
\text { hospitalized with CAP or sepsis }\end{array}$ & 7 \\
\hline
\end{tabular}

Risk Factors for Community-Acquired Pneumonia in Adults
Respiration 2017;94:299-311

DOI: $10.1159 / 000479089$ 
Table 2 (continued)

\begin{tabular}{|c|c|c|c|c|c|}
\hline $\begin{array}{l}\text { First author, } \\
\text { country }\end{array}$ & $\begin{array}{l}\text { Year } \\
\text { [Ref.] }\end{array}$ & Design & Number of participants & Age and representativeness & $\begin{array}{l}\text { NOS } \\
\text { quality } \\
\text { score }\end{array}$ \\
\hline $\begin{array}{l}\text { Juthani-Mehta, } \\
\text { USA }\end{array}$ & $2013[27]$ & Cohort & $\begin{array}{l}\text { Cohort of } 1,441 \text { participants; cases, } \\
n=193\end{array}$ & $\begin{array}{l}70-79 \text { years; hospitalized pneumonia cases, } \\
\text { community-dwelling adults with dental } \\
\text { examination (follow-up } 10 \text { years) }\end{array}$ & 8 \\
\hline Kang, Korea & $2008[28]$ & Case-control & Cases, $n=255$; controls, $n=255$ & $\begin{array}{l}\text { Only male soldiers } 18-23 \text { years old; } \\
\text { hospitalized cases and controls }\end{array}$ & 6 \\
\hline Koivula, Finland & $1994[29]$ & Cohort & $\begin{array}{l}\text { Cohort of } 4,175 \text { participants; cases, } \\
n=185\end{array}$ & $\begin{array}{l}\geq 60 \text { years; all inhabitants of Varkaus } \\
\text { (population cohort) (follow-up } 3 \text { years) }\end{array}$ & 9 \\
\hline Loeb, Canada & $2009[30]$ & Case-control & Cases, $n=717$; controls, $n=867$ & $\begin{array}{l}\geq 65 \text { years; population controls, cases presented } \\
\text { to emergency departments, controls from the } \\
\text { same catchment area }\end{array}$ & 7 \\
\hline $\begin{array}{l}\text { Meijvis, The } \\
\text { Netherlands }\end{array}$ & $2011[31]$ & Case-control & Cases, $n=430$; controls, $n=1,720$ & $\begin{array}{l}\text { Adults, age ranges not stated; hospitalized } \\
\text { cases, population controls }\end{array}$ & 9 \\
\hline Merchant, USA & $\begin{array}{l}2004[32] \\
2005[33]\end{array}$ & Cohort & $\begin{array}{l}\text { HPFS cohort of } 38,378 \text { men, } 446 \text { cases } \\
\text { observed for } 145,878 \text { person-years }\end{array}$ & Only health professionals $40-75$ years; men & 5 \\
\hline $\begin{array}{l}\text { Neupane, } \\
\text { Canada }\end{array}$ & $2010[34]$ & Case-control & Cases, $n=365$; controls, $n=494$ & $\begin{array}{l}\geq 65 \text { years; hospitalized cases, population } \\
\text { controls }\end{array}$ & 8 \\
\hline Palmer, UK & $2003[35]$ & Case-control & Cases, $n=525$; controls, $n=1,122$ & $\begin{array}{l}\text { Only men } 20-64 \text { years of age; hospitalized } \\
\text { cases and controls }\end{array}$ & 6 \\
\hline Paul, USA & $2015[36]$ & $\begin{array}{l}\text { Nested } \\
\text { case-control }\end{array}$ & Cases, $n=1,039$; controls, $n=2,022$ & $\begin{array}{l}\text { Community-dwelling immunocompetent } \\
\text { adults } 65-94 \text { years of age }\end{array}$ & 8 \\
\hline $\begin{array}{l}\text { Piednoir, } \\
\text { France }\end{array}$ & 2003 [37] & Case-control & Cases, $n=101 ;$ control, $n=101$ & $\geq 80$ years; hospitalized cases and controls & 8 \\
\hline Riquelme, Spain & $1996[38]$ & Case-control & Cases, $n=101 ;$ control, $n=101$ & $>65$ years; hospitalized cases and controls & 8 \\
\hline $\begin{array}{l}\text { Vila-Córcoles, } \\
\text { Spain }\end{array}$ & $\begin{array}{l}2005[39] \\
2009[40]\end{array}$ & Cohort & $\begin{array}{l}\text { Cohort of } 11,241 \text { subjects; } 117 \text { cases } \\
\text { observed for } 11,025 \text { person-years }\end{array}$ & $\begin{array}{l}\geq 65 \text { years; outpatient pneumonia cases in a } \\
\text { population-based cohort (follow-up } 1 \text { year) }\end{array}$ & 9 \\
\hline
\end{tabular}

CAP, community-acquired pneumonia; NOS, Newcastle-Ottawa Scale; HPFS, Health Professionals Follow-Up Study.

to counteract the aggressive invasion of other people's cigarette smoke.

Poor nutritional status, which in the different studies encompassed hypoalbuminemia, hypoproteinemia, malnourishment, or a low nutritional score, was a strong predictor of CAP. Despite the lack of a standardized definition to identify frail older adults, functional impairment assessed according to different criteria was a clear risk factor for CAP.

Environmental substances are known to be involved in the pathogenesis of lung diseases (bronchitis, bronchiolitis, asthma, COPD, and lung cancer) and this review shows their effect on CAP. However, this effect may vary according to the different substances (metals, dust, fumes, etc.), settings (home, occupational environment), extent, and definitions of environmental exposures. The transmission, control, and treatment of pneumonias acquired at the workplace represent intriguing and challenging areas of concern to epidemiologists and clinicians.

We also found that chronic bronchitis, COPD, and asthma were definitive risk factors for CAP. In some studies $[8,23]$, an effect of inhaled drugs on the risk of CAP was observed in COPD and asthma patients after adjusting for the effect of other respiratory diseases (and their concomitant treatments) and other nonrespiratory risk factors for CAP, including vaccines [8]. There are 8 studies assessing the effect of inhalation therapy on the risk of CAP. Four of them showed a significant effect of inhalers as a risk factor for CAP, while the other 4 studies, of similar methodological quality, obtained no significant and conclusive results. The lack of consistency among the studies may be due to differences in study design, type of the drug inhaled, number of puffs per day, or severity of the underlying disease (asthma or COPD) or differences 


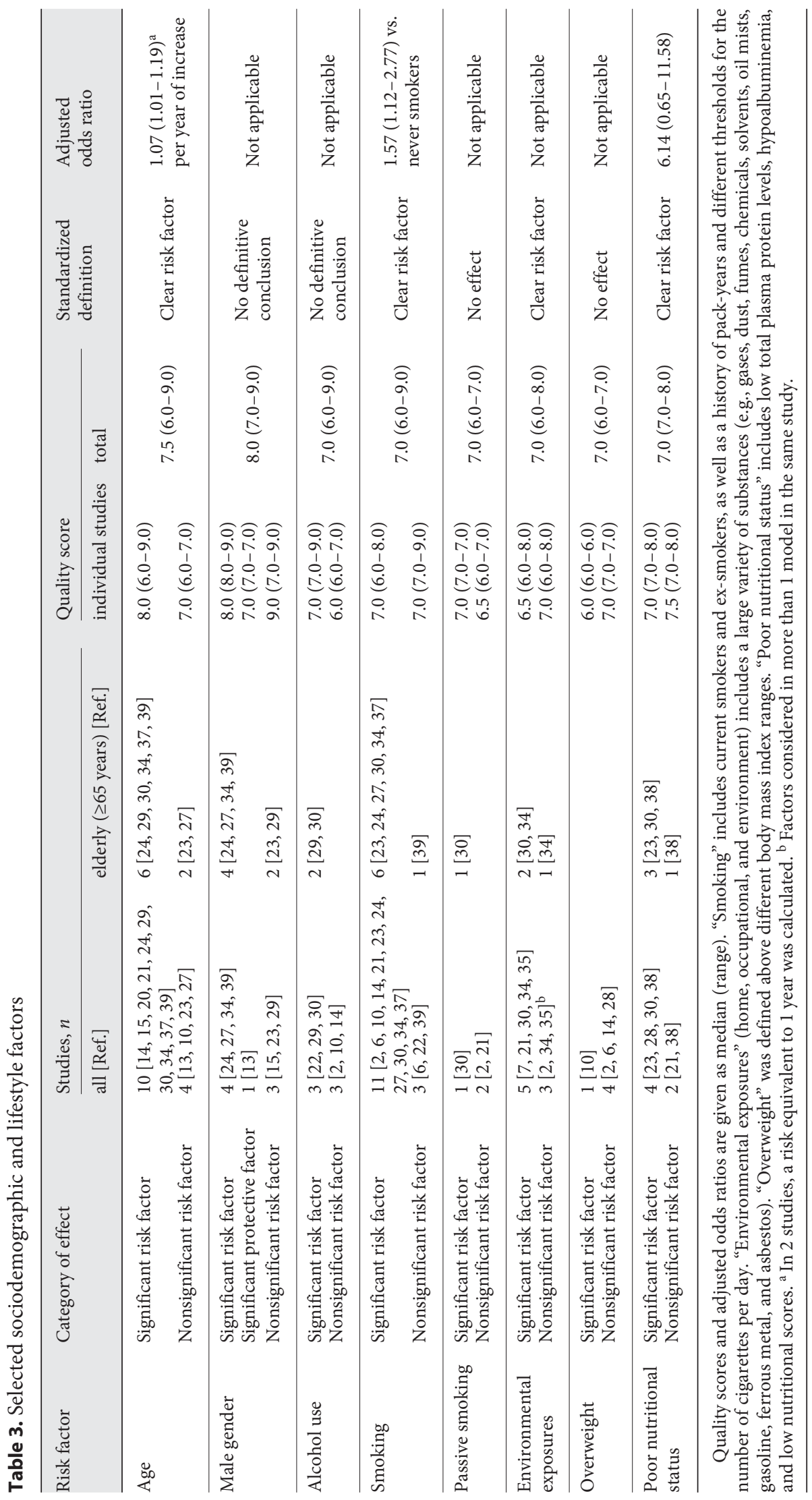




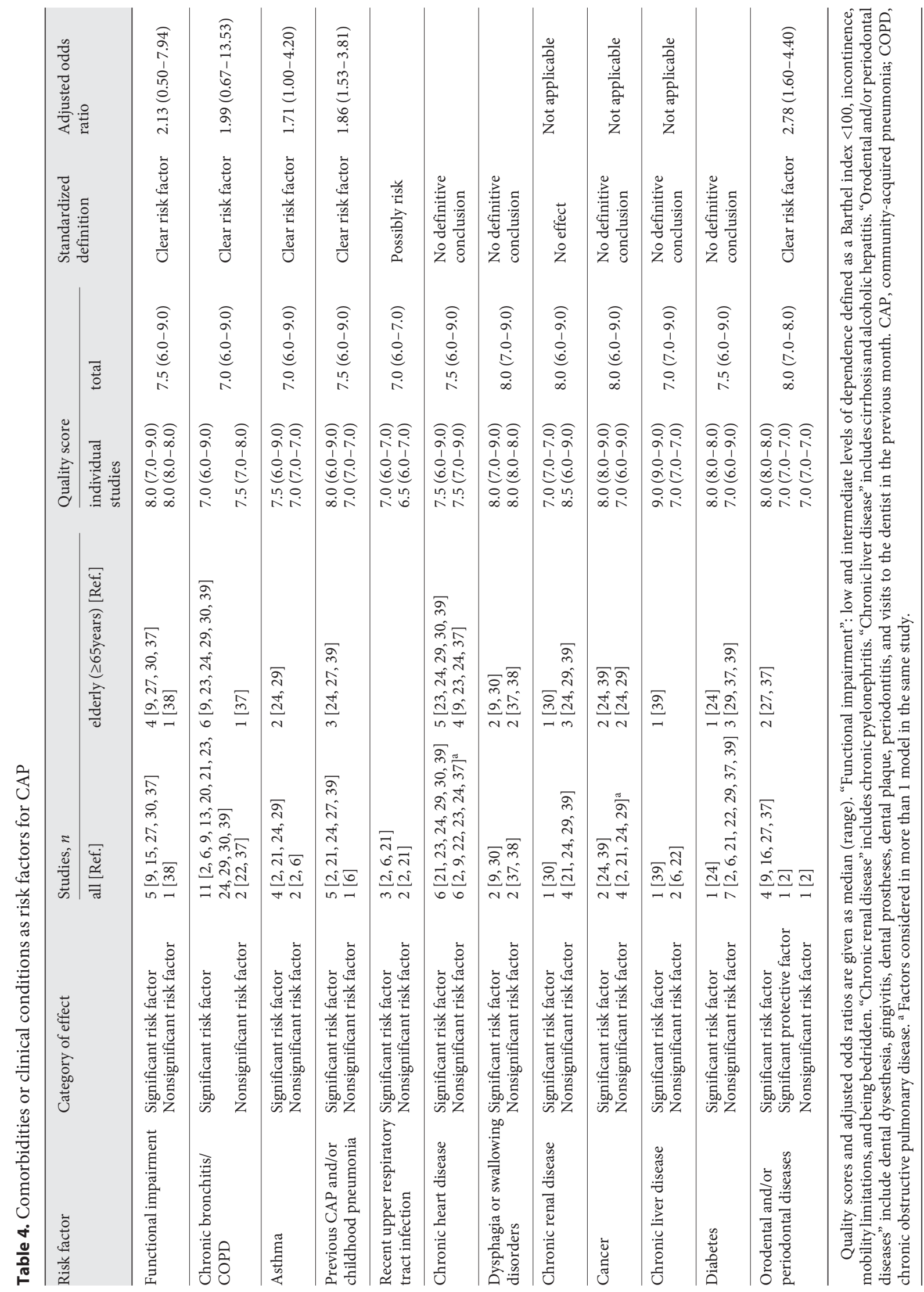




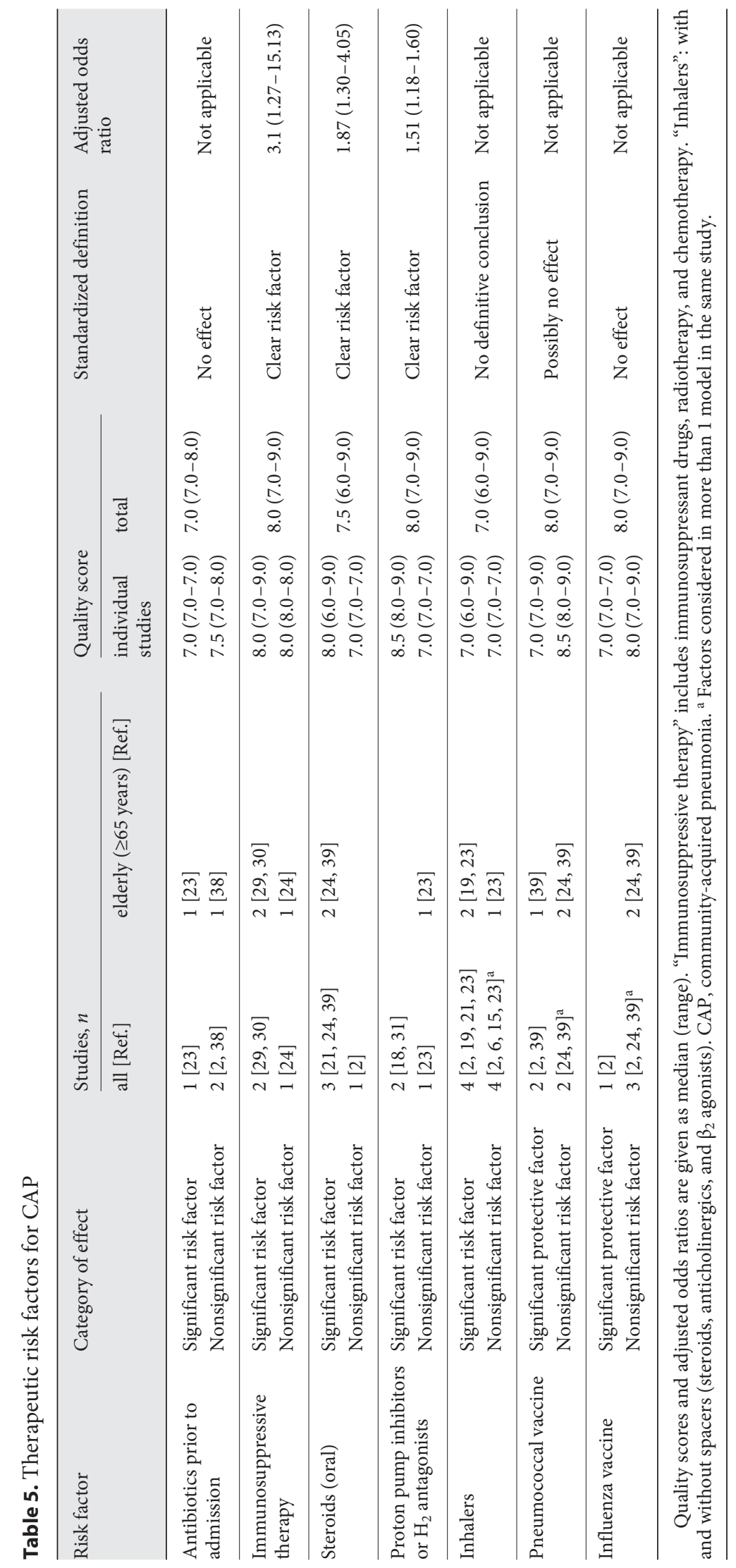


Table 6. Other, less studied potential risk factors for CAP

\begin{tabular}{|c|c|c|c|c|c|c|}
\hline \multirow[t]{2}{*}{ Factors } & \multicolumn{2}{|c|}{ Significant risk factor } & \multicolumn{2}{|c|}{ Nonsignificant risk factor } & \multicolumn{2}{|c|}{ Significant protective factor } \\
\hline & $\begin{array}{l}\text { studies, } n \\
\text { [Ref.] }\end{array}$ & quality score & $\begin{array}{l}\text { studies, } n \\
\text { [Ref.] }\end{array}$ & quality score & $\begin{array}{l}\text { studies, } n \\
\text { [Ref.] }\end{array}$ & quality score \\
\hline \multicolumn{7}{|l|}{ Sociodemographic and lifestyle } \\
\hline Ethnicity/race (Caucasian) & $1[27]$ & $8.0(8.0-8.0)$ & & & & \\
\hline Civil status ${ }^{\mathrm{a}}$ & $1[2]$ & $7.0(7.0-7.0)$ & & & $1[30]$ & $7.0(7.0-7.0)$ \\
\hline Education level & $1[34]$ & $8.0(8.0-8.0)$ & $1[2]$ & $7.0(7.0-7.0)$ & & \\
\hline Living at home & & & & & $1[30]$ & $7.0(7.0-7.0)$ \\
\hline Usual contact with children & & & $1[2]$ & $7.0(7.0-7.0)$ & & \\
\hline Physical activity (MET hour score) & & & $2[10,14]$ & $6.0(6.0-6.0)$ & $1[10]$ & $6.0(6.0-6.0)$ \\
\hline Military trainee & $1[28]$ & $7.0(7.0-7.0)$ & & & & \\
\hline Deficient social support & $2[21,30]$ & $6.5(6.0-7.0)$ & & & & \\
\hline Sudden temperature changes at work & $1[2]$ & $7.0(7.0-7.0)$ & & & & \\
\hline Poor quality of life & & & $1[38]$ & $8.0(8.0-8.0)$ & & \\
\hline Contact with pets & & & $1[2]$ & $7.0(7.0-7.0)$ & & \\
\hline Season (Winter) & $1[37]$ & $8.0(8.0-8.0)$ & & & & \\
\hline \multicolumn{7}{|l|}{ Comorbidities or clinical conditions } \\
\hline Outpatient visits in previous 1 or 2 years & $1[24]$ & $8.0(8.0-8.0)$ & & & & \\
\hline Hospital admission in previous 5 years & $1[2]$ & $7.0(7.0-7.0)$ & & & & \\
\hline HTLV-1 positive & $1[13]$ & $7.0(7.0-7.0)$ & & & & \\
\hline Total cholesterol $<100 \mathrm{mg} / \mathrm{dL}$ & & & & & $1[28]$ & $7.0(7.0-7.0)$ \\
\hline Any fatty acid intake & $1[10]$ & $6.0(6.0-6.0)$ & $2[10,32]$ & $5.5(5.0-6.0)$ & $1[32]$ & $5.0(5.0-5.0)$ \\
\hline Epilepsy & $1[2]$ & $7.0(7.0-7.0)$ & & & & \\
\hline HIV infection & & & $1[2]$ & $7.0(7.0-7.0)$ & & \\
\hline Stroke & $1[24]$ & $8.0(8.0-8.0)$ & $1[37]$ & $8.0(8.0-8.0)$ & & \\
\hline Thyroid dysfunction & & & $1[29]$ & $9.0(9.0-9.0)$ & & \\
\hline Connective tissue diseases & $1[13]$ & $7.0(7.0-7.0)$ & $1[29]$ & $9.0(9.0-9.0)$ & & \\
\hline Pulmonary tuberculosis & & & $2[2,6]$ & $7.0(7.0-7.0)$ & & \\
\hline Anemia & & & $1[17]$ & $8.0(8.0-8.0)$ & & \\
\hline Depression & & & $1[2]$ & $7.0(7.0-7.0)$ & & \\
\hline Dementia & $1[24]$ & $7.0(7.0-7.0)$ & $1[2]$ & $7.0(7.0-7.0)$ & & \\
\hline Psychiatric disorders & & & $1[2]$ & $7.0(7.0-7.0)$ & & \\
\hline Vitamin D deficiency & $1[26]$ & $7.0(7.0-7.0)$ & & & & \\
\hline $\mathrm{FEV}_{1}$ & $1[27]$ & $8.0(8.0-8.0)$ & & & & \\
\hline Gastroesophageal reflux disease & & & $1[37]$ & $8.0(8.0-8.0)$ & & \\
\hline $\begin{array}{l}\text { Interventions on the upper respiratory tract in } \\
\text { previous month }\end{array}$ & & & $1[2]$ & $7.0(7.0-7.0)$ & & \\
\hline \multicolumn{7}{|l|}{ Therapeutic risk factors } \\
\hline Amiodarone & $1[2]$ & $8.0(8.0-8.0)$ & & & & \\
\hline Benzodiazepines & & & & & $1[6]$ & $7.0(7.0-7.0)$ \\
\hline $\mathrm{N}$-acetylcysteine & $1[2]$ & $7.0(7.0-7.0)$ & $1[2]$ & $7.0(7.0-7.0)$ & & \\
\hline Atypical antipsychotics & $1[23]$ & $7.0(7.0-7.0)$ & & & & \\
\hline Aminophylline/xanthines & $2[2,6]$ & $7.0(7.0-7.0)$ & & & & \\
\hline Plastic pear spacers & & & $1[6]$ & $7.0(7.0-7.0)$ & & \\
\hline Medication with 5 different drugs per day & $1[37]$ & $8.0(8.0-8.0)$ & & & & \\
\hline Iron supplement & & & $1[23]$ & $7.0(7.0-7.0)$ & & \\
\hline Narcotics & & & $1[23]$ & $7.0(7.0-7.0)$ & & \\
\hline Nonsteroidal anti-inflammatory drugs & & & $1[23]$ & $7.0(7.0-7.0)$ & & \\
\hline Any vitamin intake & & & $2[10,32]$ & $5.5(5.0-6.0)$ & $1[10]$ & $6.0(6.0-6.0)$ \\
\hline Digoxin & & & $1[2]$ & $7.0(7.0-7.0)$ & & \\
\hline Diuretics & & & $1[2]$ & $7.0(7.0-7.0)$ & & \\
\hline Oxygen therapy & $2[2,24]$ & $7.0(7.0-7.0)$ & & & & \\
\hline Anticholinergics (oral) & $1[36]$ & $8.0(8.0-8.0)$ & & & & \\
\hline
\end{tabular}

Quality scores are given as median (range). CAP, community-acquired pneumonia; MET, metabolic equivalents; HTLV-1, human T-lymphotropic virus $1 ; \mathrm{FEV}_{1}$, forced expiratory volume in $1 \mathrm{~s}$ (severe vs. mild/normal). ${ }^{\mathrm{a}}$ Married or living with a partner vs. widowed/divorced/living alone. 
in the use of spacers. Thus, a definitive conclusion regarding inhalation therapy has not yet been reached, and further research is required.

Likewise, in the observational studies, "possibly no effect" or "no effect" was obtained for the role of 23 -valent pneumococcal polysaccharide and influenza vaccination, respectively, as a protective factor against CAP. The protective effect of vaccination should be better assessed in randomized clinical trials. The results of this systematic review agree with those of a meta-analysis of the efficacy of pneumococcal vaccination in adults, which also concluded that vaccination does not appear to be effective in preventing pneumonia [41, 42]. However, meta-analyses have produced conflicting results for the efficacy of 23-valent pneumococcal polysaccharide vaccine $[43,44]$. A 13 -valent pneumococcal conjugate vaccine (PCV13) is now available for the prevention of pneumonia and invasive pneumococcal disease caused by PCV13 serotypes in adults. In a randomized, double-blind, placebo-controlled trial involving 84,496 adults $\geq 65$ years of age, PCV 13 was effective in preventing vaccine-type pneumococcal, bacteremic, and nonbacteremic $\mathrm{CAP}$ and vaccine-type invasive pneumococcal disease, but not in preventing CAP from any cause [45]. The role of influenza vaccination as a protective factor against CAP is also unclear [46, 47].

On the other hand, it has been argued that inappropriate antibiotic use increases bacterial resistance to common antibiotics and also alters the normal bacterial flora of the host [48]. Nonetheless, only 1 out of 3 reviewed studies found an association between a recent history of taking antibiotics and CAP [23]. Hence, the few available studies and their lower quality lead us to conclude that previous consumption of antibiotics has no effect on the risk of CAP. Ideally, it would be desirable to have more studies to answer this important question.

It has been reported that the use of gastric acid-suppressive therapy (proton pump inhibitors and $\mathrm{H}_{2}$ receptor antagonists) increases the risk of CAP [49], particularly if treatment has been recently started $[18,31]$. It has been suggested that a reduction of gastric acid secretion facilitates pathogen colonization of the upper gastrointestinal tract and oral infections [49]. However, other studies do not support a pharmacological effect of gastric acid suppressors on the risk of CAP $[2,50]$. This review concludes that treatment with gastric acid-suppressive drugs is a risk factor for CAP. This finding is clinically relevant because acid-suppressive drugs are commonly prescribed for complaints of dyspepsia and gastroesophageal reflux disease and their effectiveness in the treatment of upper gastrointestinal symptoms is excellent. However, the use of

Risk Factors for Community-Acquired Pneumonia in Adults these drugs may be reconsidered for patients with other risk factors for CAP, such as elderly subjects, persons with COPD or asthma, and immunocompromised persons.

Use of oral steroids and immunosuppressive therapy were also clear risk factors for CAP. The increased risk of infectious complications is an important safety concern when prescribing immunosuppressive therapy. Prevention of infection is a key management strategy, to which early recognition of other associated risk factors for CAP should be added.

Interestingly, poor oral health and orodental diseases increased the risk of CAP both in elderly subjects and in the general population. Dental plaque and dental prostheses favor colonization and may constitute a reservoir for respiratory pathogens [51]. Prevention of the accumulation of plaque and bacterial colonization, particularly in subjects with dental prostheses, dental caries, and periodontal disease, is an important practical consequence of our findings. Regular dental examinations and good oral hygiene should be recommended.

Other comorbidities, such as chronic heart disease, renal dysfunction, liver disease, diabetes, cancer, and dysphagia or swallowing disorders, had no effect, or no definitive conclusions could be drawn. Moreover, the effect of other potential risk factors for CAP identified in the present review should be confirmed in further studies. These include a large number of factors, such as the role of civil status, ethnicity, usual contact with children, deficient social support, sudden temperature changes at the workplace, impaired quality of life, physical activity, previous outpatient visits and hospital admissions, HTLV-1 (human T-lymphotropic virus 1) and HIV infections, epilepsy, stroke, thyroid dysfunction, connective tissue diseases, pulmonary tuberculosis, anemia, depression, dementia, and oxygen therapy, as well as treatment with amiodarone, benzodiazepines, $\mathrm{N}$-acetylcysteine, atypical antipsychotics, aminophylline, narcotics, nonsteroidal anti-inflammatory drugs, motility agents, iron supplementation, vitamins, digoxin, and diuretics. All these factors have been inconsistently assessed in a few individual studies, and no definitive conclusions could be reached.

Observational studies are vulnerable to various sources of bias, and the evidence obtained by them is less robust than evidence derived from experimental studies. The present findings should be interpreted taking into account this limitation, but the clinical questions posed in this review could only be answered reasonably through observational designs. One of the main difficulties of this systematic review lies in the unavoidable heterogeneity of studies in terms of populations, risk factors analyzed, lengths of

Respiration 2017;94:299-311 DOI: $10.1159 / 000479089$ 
follow-up, and statistical methods, including differences in adjusting for confounding variables and covariates both within and between studies. By contrast, strengths of the present systematic review include the comprehensive literature search, the use of sound methodological review techniques, the use of a well-established tool (NOS) for quality assessment of the individual studies, the high quality scores obtained for the included studies, and the weighted conclusions based on the quality of the evidence.

The present results provide robust current evidence of the importance of age, smoking, malnutrition, environmental exposures, previous CAP, chronic bronchitis/ COPD, asthma, functional impairment, poor dental health, immunosuppressive therapy, oral steroids, and gastric acid-suppressive drugs as definitive risk factors for CAP. Clinicians should be aware of these risk factors, because some of them are modifiable and amenable to effective interventions. Special attention should be devoted to oral hygiene, antacid drug reduction, functional impairment monitoring, and rehabilitation protocols. Implementation of the findings of the present systematic review into daily practice is clinically relevant, since early recognition and adequate management of those factors that are modifiable may reduce CAP-associated morbidity and mortality among adults, particularly elderly individuals.

\section{Acknowledgements}

The authors thank Centro Cochrane Iberoamericano for methodological support and Marta Pulido, MD, for editing the manuscript and editorial assistance. The fees for medical editing were paid by Fundació Privada Salut del Consorci Sanitari del Maresme.

\section{Financial Disclosure and Conflicts of Interest}

No conflicts of interest are to be declared. No funding in the form of grants or other support was received for this study.

\section{Author Contributions}

J.A. participated in the study design, selection of studies for inclusion in the review, assessment of the quality of articles, interpretation of the analysis, and writing of the manuscript. M.S.-P. carried out the search of the literature, selection of studies for inclusion in the review, selection of criteria for the analysis, assessment of the quality of articles, statistical analysis, interpretation of the data, and writing of the manuscript. I.B. participated in the study design, methodological assessment, selection of criteria for the analysis, assessment of the quality of articles, and writing of the manuscript. V.B. was involved in the methodological assessment, assessment of the quality of articles, analysis of the data, synthesis of the results, and critical review of the content of the manuscript. All authors read and approved the final manuscript.

\section{References}

1 Ewig S, Torres A: Community-acquired pneumonia as an emergency: time for an aggressive intervention to lower mortality. Eur Respir J 2011;38:253-260.

2 Almirall J, Bolíbar I, Serra-Prat M, Roig J, Hospital I, Carandell E, Agustí M, Ayuso P, Estela A, Torres A: New evidence of risk factors for community-acquired pneumonia: a population-based study. Eur Respir J 2008;31: 1274-1284

3 Kohlhammer Y, Schwartz M, Raspe H, Schäfer T: Risk factors for community acquired pneumonia (CAP). A systematic review (in German). Dtsch Med Wochenschr 2005; 130:381-386.

4 Moher D, Liberati A, Tetzlaff J, Altman DG; PRISMA Group: Preferred reporting items for systematic reviews and meta-analyses: the PRISMA statement. Ann Intern Med 2009;15: 264-269.

5 Wells GA, Shea B, O'Connell D, Peterson J, Welch V, Losos M, et al: The Newcastle-Ottawa Scale (NOS) for assessing the quality of nonrandomised studies in meta-analyses. The Ottawa Hospital Research Institute. 2014. http://www. ohri.ca/programs/clinical_epidemiology/oxford.asp (accessed December 14, 2015).
6 Almirall J, Bolíbar I, Balanzó X, González CA: Risk factors for community-acquired pneumonia in adults: a population-based casecontrol study. Eur Respir J 1999;13:349-355.

7 Almirall J, Serra-Prat M, Bolíbar I, Palomera E, Roig J, Boixeda R, Bartolomé M, de la Torre $\mathrm{M}$, Parra O, Torres A: Professions and working conditions associated with communityacquired pneumonia (in English, Spanish). Arch Bronconeumol 2015;51:627-631.

8 Almirall J, Bolíbar I, Serra-Prat M, Palomera E, Roig J, Hospital I, Carandell E, Agustí M, Ayuso P, Estela A, Torres A; Community-Acquired Pneumonia in Catalan Countries: Inhaled drugs as risk factors for community-acquired pneumonia. Eur Respir J 2010;36: 1080-1087.

9 Almirall J, Rofes L, Serra-Prat M, Icart R, Palomera E, Arreola V, Clavé P: Oropharyngeal dysphagia is a risk factor for communityacquired pneumonia in the elderly. Eur Respir J 2013;41:923-928.

10 Alperovich M, Neuman MI, Willett WC, Curhan GC: Fatty acid intake and the risk of community-acquired pneumonia in US women. Nutrition 2007;23:196-202.
11 Neuman MI, Willett WC, Curhan GC: Vitamin and micronutrient intake and the risk of community-acquired pneumonia in US women. Am J Med 2007;120:330-336.

12 Neuman MI, Willett WC, Curhan GC: Physical activity and the risk of community-acquired pneumonia in US women. Am J Med 2010;123:281.e7-281.e11.

13 Atsumi E, Yara S, Higa F, Hirata T, Haranaga S, Tateyama M, Fujita J: Influence of human T lymphotropic virus type I infection on the etiology of community-acquired pneumonia. Intern Med 2009;48:959-965.

14 Baik I, Curhan GC, Rimm EB, Bendich A, Willett WC, Fawzi WW: A prospective study of age and lifestyle factors in relation to community-acquired pneumonia in US men and women. Arch Intern Med 2000;160:30823088.

15 Dang TT, Eurich DT, Weir DL, Marrie TJ, Majumdar SR: Rates and risk factors for recurrent pneumonia in patients hospitalized with community-acquired pneumonia: population-based prospective cohort study with 5 years of follow-up. Clin Infect Dis 2014;59: $74-80$. 
16 de Melo Neto JP, Melo MS, Dos SantosPereira SA, Martinez EF, Okajima LS, SabaChujfi E: Periodontal infections and community-acquired pneumonia: a case-control study. Eur J Clin Microbiol Infect Dis 2013; 32:27-32.

17 Doshi SM, Rueda AM, Corrales-Medina VF, Musher DM: Anemia and community-acquired pneumococcal pneumonia. Infection 2011;39:379-383.

18 Eurich DT, Sadowski CA, Simpson SH, Marrie TJ, Majumdar SR: Recurrent communityacquired pneumonia in patients starting acidsuppressing drugs. Am J Med 2010;123:47-53.

19 Eurich DT, Lee C, Marrie TJ, Majumdar SR: Inhaled corticosteroids and risk of recurrent pneumonia: a population-based, nested casecontrol study. Clin Infect Dis 2013;57:11381144.

20 Farr BM, Bartlett CLR, Wadsworth J, Miller DL: Risk factors for community-acquired pneumonia diagnosed upon hospital admission. Respir Med 2000;94:954-963.

21 Farr BM, Woodhead MA, Macfarlane JT, Bartlett CL, McCraken JS, Wadsworth J, Miller DL: Risk factors for community-acquired pneumonia diagnosed by general practitioners in the community. Respir Med 2000;94: 422-427.

22 Fernández-Solá J, Junqué A, Estruch R, Monforte R, Torres A, Urbano-Márquez A: High alcohol intake as a risk and prognostic factor for community-acquired pneumonia. Arch Intern Med 1995;155:1649-1654.

23 Gau JT, Acharya U, Khan S, Heh V, Mody L, Kao TC: Pharmacotherapy and the risk for community-acquired pneumonia. BMC Geriatr 2010;10:45.

24 Jackson LA, Neuzil KM, Yu, Benson P, Barlow WE, Adams AL, Hanson CA, Mahoney LD, Shay DK, Thompson WW: Effectiveness of pneumococcal polysaccharide vaccine in older adults. N Engl J Med 2003;348:17471755.

25 Jackson ML, Neuzil KM, Thompson WW, Shay DK, Yu O, Hanson CA, Jackson LA: The burden of community-acquired pneumonia in seniors: results of a population-based study. Clin Infect Dis 2004;39:1642-1650.

26 Jovanovich AJ, Ginde AA, Holmen J, Jablonski K, Allyn RL, Kendrick J, Chonchol M: Vitamin D level and risk of community-acquired pneumonia and sepsis. Nutrients 2014;6:2196-2205.

27 Juthani-Mehta M, De Rekeneire N, Allore H, Chen S, O'Leary JR, Bauer DC, Harris TB, Newman $A B$, Yende S, Weyant RJ, Kritchevsky S, Quagliarello V; Health ABC Study: Modifiable risk factors for pneumonia requiring hospitalization of community-dwelling older adults: the Health, Aging, and Body Composition Study. J Am Geriatr Soc 2013;61:1111-1118.

28 Kang DR, Kim YK, Park MS, Kim YS, Ko DH, Kim C: Low levels of serum cholesterol and albumin and the risk of community-acquired pneumonia in young soldiers. Int J Tuberc Lung Dis 2008;12:26-32.
29 Koivula I, Sten M, Mäkelä PH: Risk factors for pneumonia in the elderly. Am J Med 1994;96: 313-320.

30 Loeb M, Neupane B, Walter SD, Hanning R, Carusone SC, Lewis D, Krueger P, Simor AE, Nicolle L, Marrie TJ: Environmental risk factors for community-acquired pneumonia hospitalization in older adults. J Am Geriatr Soc 2009;57:1036-1040.

31 Meijvis SC, Cornips MC, Voorn GP, Souverein PC, Endeman H, Biesma DH, Leufkens HG, van de Garde EM: Microbial evaluation of proton-pump inhibitors and the risk of pneumonia. Eur Respir J 2011;38:1165-1172.

32 Merchant AT, Curhan G, Bendich A, Singh VN, Willett WC, Fawzi WW: Vitamin intake is not associated with community-acquired pneumonia in US men. J Nutr 2004;134:439444.

33 Merchant AT, Curhan GC, Rimm EB, Willett WC, Fawzi WW: Intake of $n-6$ and $n-3$ fatty acids and fish and risk of community-acquired pneumonia in US men. Am J Clin Nutr 2005;82:668-674.

34 Neupane B, Jerrett M, Burnett RT, Marrie T, Arain A, Loeb M: Long-term exposure to ambient air pollution and risk of hospitalization with community-acquired pneumonia in older adults. Am J Respir Crit Care Med 2010; 181:47-53

35 Palmer KT, Poole J, Ayres JG, Mann J, Burge PS, Coggon D: Exposure to metal fume and infectious pneumonia. Am J Epidemiol 2003; 157:227-233

36 Paul KJ, Walker RL, Dublin S: Anticholinergic medications and risk of community-acquired pneumonia in elderly adults: a population-based case-control study. J Am Geriatr Soc 2015;63:476-485.

37 Piednoir E, Novella JL, Bureau-Chalot F, Jolly D, Blanchard F: Risk factors for community acquired pneumonia in persons older than 80 years. (Article in French). Rev Geriatr 2003; 28:789-798.

38 Riquelme R, Torres A, El-Ebiary M, de la Bellacasa JP, Estruch R, Mensa J, Fernández-Solá J, Hernández C, Rodriguez-Roisin R: Community-acquired pneumonia in the elderly: a multivariate analysis of risk and prognostic factors. Am J Respir Crit Care Med 1996;154: 1450-1455.

39 Vila-Córcoles A, Ochoa-Gondar O, Llor C, Hospital I, Rodríguez T, Gómez A: Protective effect of pneumococcal vaccine against death by pneumonia in elderly subjects. Eur Respir J 2005;26:1086-1091.

40 Vila-Córcoles A, Ochoa-Gondar O, Rodríguez-Blanco T, Raga-Luria X, Gomez-Bertomeu F; EPIVAC Study Group: Epidemiology of community-acquired pneumonia in older adults: a population-based study. Respir Med 2009;103:309-316.

41 Huss A, Scott P, Stuck AE, Trotter C, Egger M: Efficacy of pneumococcal vaccination in adults: a meta-analysis. CMAJ 2009;180: 48-58.
42 Schiffner-Rohe J, Witt A, Hemmerling J, von Eiff C, Leverkus FW: Efficacy of PPV23 in preventing pneumococcal pneumonia in adults at increased risk - a systematic review and meta-analysis. PLoS One 2016;11: e0146338.

43 Diao WQ, Shen N, Yu PX, Liu BB, He B: Efficacy of 23-valent pneumococcal polysaccharide vaccine in preventing community-acquired pneumonia among immunocompetent adults: a systematic review and meta-analysis of randomized trials. Vaccine 2016;34:1496-1503.

44 Kraicer-Melamed H, O'Donnell S, Quach C: The effectiveness of pneumococcal polysaccharide vaccine 23 (PPV23) in the general population of 50 years of age and older: a systematic review and meta-analysis. Vaccine 2016;34:1540-1550.

45 Bonten MJ, Huijts SM, Bolkenbaas M, Webber C, Patterson S, Gault S, van Werkhoven $\mathrm{CH}$, van Deursen AM, Sanders EA, Verheij TJ, Patton M, McDonough A, MoradoghliHaftvani A, Smith H, Mellelieu T, Pride MW, Crowther G, Schmoele-Thoma B, Scott DA, Jansen KU, Lobatto R, Oosterman B, Visser N, Caspers E, Smorenburg A, Emini EA, Gruber WC, Grobbee DE: Polysaccharide conjugate vaccine against pneumococcal pneumonia in adults. N Engl J Med 2015;372:11141125.

46 Osterholm MT, Kelley NS, Sommer A, Belongia EA: Efficacy and effectiveness of influenza vaccines: a systematic review and meta-analysis. Lancet Infect Dis 2012;12:36-44.

47 Gubbins PO, Li C: The influence of influenza and pneumococcal vaccines on communityacquired pneumonia (CAP) outcomes among elderly patients. Curr Infect Dis Rep 2015;17: 49.

48 Jenkins TC, Sakai J, Knepper BC, Swartwood CJ, Haukoos JS, Long JA, Price CS, Burman WJ: Risk factors for drug-resistant Streptococcus pneumoniae and antibiotic prescribing practices in outpatient community-acquired pneumonia. Acad Emerg Med 2012;19:703706.

49 Laheij RJ, Sturkenboom MC, Hassing RJ, Dieleman J, Stricker BH, Jansen JB: Risk of community-acquired pneumonia and use of gastric acid-suppressive drugs. JAMA 2004;292: 1955-1960.

50 Filion KB, Chateau D, Targownik LE, Gershon A, Durand M, Tamim H, Teare GF, Ravani P, Ernst P, Dormuth CR; CNODES Investigators: Proton pump inhibitors and the risk of hospitalisation for community-acquired pneumonia: replicated cohort studies with meta-analysis. Gut 2014;63:552-558.

51 Rodriguez F, Bolíbar I, Serra-Prat M, Palomera E, Ballester MV, Almirall J; on behalf of the Community-Acquired Pneumonia in Catalan Countries (PACAP): Poor oral health as risk factor for community-acquired pneumonia. J Pulm Respir Med 2014; 4:203.
Risk Factors for Community-Acquired Pneumonia in Adults
Respiration 2017;94:299-311 DOI: $10.1159 / 000479089$ 